\title{
Genetic lactase non-persistence, consumption of milk products and intakes of milk nutrients in Finns from childhood to young adulthood
}

\author{
Marika M. L. Laaksonen ${ }^{1}$, Vera Mikkilä ${ }^{1}$, Leena Räsänen ${ }^{1}$, Riikka Rontu ${ }^{2}$, Terho J. Lehtimäki ${ }^{3,4}$, \\ Jorma S. A. Viikari ${ }^{5}$, Olli T. Raitakari ${ }^{6}$ and the Cardiovascular Risk in Young Finns Study Group \\ ${ }^{1}$ Division of Nutrition, Department of Applied Chemistry and Microbiology, University of Helsinki, PO Box 66, FIN-00014, Finland \\ ${ }^{2}$ Centre for Laboratory Medicine, Tampere University Hospital, PO Box 2000, FIN-33521 Tampere, Finland \\ ${ }^{3}$ Laboratory of Atherosclerosis Genetics, Tampere University Hospital, PO Box 2000, FIN-33521 Tampere, Finland \\ ${ }^{4}$ Department of Clinical Chemistry, University of Tampere Medical School, 33014 University of Tampere, Finland \\ ${ }^{5}$ Department of Medicine, Turku University Central Hospital, Kiinamyllynkatu 4-8, FIN-20520 Turku, Finland \\ ${ }^{6}$ Department of Clinical Physiology, Turku University Central Hospital, FIN-20521 Turku, Finland
}

(Received 14 May 2008 - Revised 21 October 2008 - Accepted 23 October 2008 - First published online 13 January 2009)

Previous evidence suggests that the lactase gene $\mathrm{C} / \mathrm{T}_{-13910}$ polymorphism (rs4988235) is associated with avoidance of milk products and lower Ca intake. We examined whether the consumption of milk and milk products and the intakes of milk nutrients differ between the lactase genotypes from childhood to young adulthood. Subjects belong to the Cardiovascular Risk in Young Finns Study where the first cross-sectional surveys were conducted in 1980 ( $n$ 3596), with follow-up studies in 1983, 1986, 1989, 1992 and 2001 ( $n$ 2620). The same dietary questionnaire was used throughout the follow-up to collect data on habitual consumption of milk and milk products in all subjects, and daily nutrient intakes were assessed with $48 \mathrm{~h}$ dietary recalls in $50 \%$ of the subjects. Subjects with the lactase non-persistence $\left(\mathrm{C} \mathrm{C}_{-13910}\right)$ genotype consumed less milk since childhood, but the consumption of other milk products did not differ between the genotypes. In adult females, the lactose content of milk products consumed was lower $(P=0.003)$, and in both sexes low-lactose and milk-free diets were more common in the $\mathrm{C} / \mathrm{C}_{-13910}$ genotype than in the other genotypes. Inadequate $\mathrm{Ca}$ intake was most common in females with the $\mathrm{C}_{-13910}$ genotype as early as in childhood (15-63\%), but in males only in adulthood $(24 \%)$. In adult females, preference for low-lactose milk and milk products equalised the differences in Ca intake between the genotypes. Thus, in those with the $\mathrm{C} / \mathrm{C}_{-13910}$ genotype, preference for low-lactose milk and milk products may decrease the risk for inadequate $\mathrm{Ca}$ intake.

Lactase genotype: Milk consumption: Calcium intake: Lactose intake

More than half of the world's population have a deficit in the enzyme lactase (lactase non-persistence) ${ }^{(1)}$. Lactase non-persistence results in the presence of maldigested lactose in the colon, which may cause unpleasant symptoms such as bloating, abdominal pain and diarrhoea. The most common therapeutic approach to lactase non-persistence is to exclude milk and milk products from the diet ${ }^{(2)}$, even though this may predispose to poorer bone health due to lowered $\mathrm{Ca}$ intake ${ }^{(3-6)}$. However, the evidence is not consistent ${ }^{(7,8)}$, and the effectiveness of milk and milk product consumption in the prevention of osteoporosis has recently been re-evaluated ${ }^{(9)}$.

Genetic lactase non-persistence is a recessively inherited condition caused by a decline in the activity of lactase-phlorizin hydrolase in the small intestine during maturation. Enattah et al. ${ }^{(10)}$ found that lactase persistence correlates strongly with the $\mathrm{C} / \mathrm{T}_{-13910}$ polymorphism located $13.9 \mathrm{~kb}$ upstream from the lactase gene. In vitro studies suggest that this polymorphism enhances lactase gene expression ${ }^{(11,12)}$ by regulating the binding of transcription factors such as
Oct- $1^{(13)}$. The expression of the lactase gene in the intestinal mucosa is several times higher for the $\mathrm{T}_{-13910}$ allele ${ }^{(14)}$. Therefore, both the $\mathrm{T} / \mathrm{T}_{-13910}$ and $\mathrm{C} / \mathrm{T}_{-13910}$ genotypes possess sufficient enzyme activity to be classified as lactase persistent, and the homozygous $\mathrm{C} / \mathrm{C}_{-13910}$ genotype is classified as lactase non-persistent.

Austrian and Estonian studies have shown that the $\mathrm{C} / \mathrm{C}_{-13910}$ genotype is associated with a lower consumption of milk and milk products, lower $\mathrm{Ca}$ intake and impaired $\mathrm{Ca}$ absorption $^{(15-18)}$. In Finland dairy products have traditionally constituted an important part of the daily diet, and milk and milk products provide about two-thirds of the $\mathrm{Ca}$ intake of adults in Finland ${ }^{(19)}$. Hence, genetic lactase non-persistence in Finns could be considered a potential risk factor for low $\mathrm{Ca}$ intake by limiting the consumption of milk and milk products. Some Finnish studies indicate that the $\mathrm{C} / \mathrm{C}_{-13910}$ genotype is linked to milk avoidance and a low-lactose diet in childhood, adolescence and adulthood ${ }^{(20-22)}$. However, Finnish studies in young men ${ }^{(23)}$, postmenopausal women ${ }^{(24)}$ 
and elderly individuals ${ }^{(25)}$ have observed no differences in the consumption of milk products or in total $\mathrm{Ca}$ intakes between the lactase genotypes. It is noteworthy that so far no evidence has been published on the differences in habitual lactose intake between the lactase genotypes.

We have investigated the $\mathrm{C} / \mathrm{T}_{-13910}$ polymorphism in the Cardiovascular Risk in Young Finns Study, which provides a prospective 21-year follow-up and well-documented longitudinal data on food consumption and nutrient intakes from early childhood until young adulthood ${ }^{(26-31)}$. A recent report from the Young Finns Study showed that the lactase gene $\mathrm{C} / \mathrm{T}_{-13910}$ polymorphism was not associated with mean growth speed but contributed significantly to milk product consumption and dietary $\mathrm{Ca}$ intake from childhood into young adulthood ${ }^{(32)}$. In this present analysis, we further examine whether the type of milk and milk products consumed and nutrient intakes from milk and milk products differ between the lactase genotypes from childhood into young adulthood. Since low-lactose milk and milk products are commonly used in Finland, our specific aim was to compare the lactose content of milk products consumed between the lactase genotypes.

\section{Subjects and methods}

\section{Cardiovascular Risk in Young Finns Study}

The Cardiovascular Risk in Young Finns Study is an ongoing multi-centre follow-up of atherosclerosis risk factors for young Finns. The first cross-sectional survey was conducted in $1980^{(26)}$. The total sample comprised 4320 subjects aged $3,6,9,12,15$ and 18 years. The subjects were randomly selected from the national population register from five university cities in Finland (Helsinki, Turku, Tampere, Kuopio and Oulu) and the rural municipalities in their vicinity. A total of 3596 subjects ( $83 \%$ of those invited) participated in 1980. The same subjects were re-examined in follow-up studies in 1983 and 1986, as well as in a 21-year follow-up in 2001 at the age of $24-39$ years (Table 1) ${ }^{(28,30)}$. In 1989 and 1992, only smaller subgroups of the original cohort were studied. In order to compare the consumption of milk and milk products between the lactase genotypes at the ages of $6,9,12,15$ and 18 years, we combined the data from the different follow-up years as marked in Table 1. Subjects provided their written informed consent, and the local ethics committees of the participating universities approved the study protocol $^{(26)}$.

\section{Dietary data}

Previous studies have described the details of the dietary study included in the project ${ }^{(27,29,31)}$. The consumption of milk and milk products was assessed with a dietary questionnaire on habitual eating behaviour and food choices, assessed at baseline in 1980 and in the follow-ups in 1983, 1986, 1989, 1992 and 2001. The questionnaire has been slightly modified over the years to fit the relevant issues according to the follow-up year and subjects' age, but has included the same set of food choices during all follow-ups. The questionnaire has always included questions on the habitual amount of milk consumed (glasses per d) and the frequency of consumption of cheese, sour milk products (buttermilk, sour whole milk, yoghurt and curd cheese) and ice cream. Since the questionnaire has been designed to assess milk fat intake, the questionnaire included a question on the type of the milk products based on their fat content. Otherwise the different milk product brands were not outlined and the lactose content of the products was not assessed. On the basis of the questionnaire data, we converted the reported frequency of consumption of milk products into portions per week $(\mathrm{p} / \mathrm{w})$ as follows: 'daily' $=7 \mathrm{p} / \mathrm{w}$; 'nearly every day' $=5 \mathrm{p} / \mathrm{w}$; 'a couple of times weekly' $=2.5 \mathrm{p} / \mathrm{w}$; 'once weekly' $=1 \mathrm{p} / \mathrm{w}$; 'once or twice monthly' $=0.5 \mathrm{p} / \mathrm{w}$; 'less or never' $=0 \mathrm{p} / \mathrm{w}$. We then added this figure up with the number of glasses of milk reported, thus resulting in an index variable representing each subject's habitual consumption of milk and milk products as portions per week (or per $\mathrm{d}$ when divided by 7). If the subjects answered none to the question 'how many glasses of milk was consumed daily', they were classified as not drinking milk. In the questionnaire the subjects reported if they followed a low-lactose or milk-free diet, but this information was based on their own reporting and was not verified with the clinical diagnosis of lactose intolerance.

The data on the subjects' daily intake of energy, $\mathrm{Ca}$, lactose and protein were obtained with a detailed $48 \mathrm{~h}$ dietary recall assessed in $50 \%$ of subjects at baseline in 1980 and in followups in 1986 and 2001. Dietary interviewers were all trained dietitians and collected information on foods and beverages consumed by subjects during the 2 d before the interview. In 1980 and 1986, 3- to 12-year-old children were interviewed together with their mothers, fathers or another accompanying person. As detailed information as possible on the type and amount of foods and drinks consumed was documented on a form by the interviewer. The food composition data in the 1980s were based on the Finnish food composition tables (maintained by the University of Helsinki) and on analytical data obtained from the

Table 1. Subjects and dietary studies in the Cardiovascular Risk in Young Finns Study

\begin{tabular}{|c|c|c|c|c|c|c|c|c|c|c|c|c|c|c|c|c|}
\hline Year & Subjects $(n)$ & $\%$ & Dietary data & & coh & $\mathrm{rts}^{\star}$ & & & & & & & & & & \\
\hline 1980 & 3596 & 100 & Questionnaire and $48 \mathrm{~h}$ recall (50\%) & 3 & 6 & 9) & 12) & 15) & 18) & & & & & & & \\
\hline 1983 & 2991 & 83 & Questionnaire & & $6\}$ & $9\}$ & 12 & 15 & 18 & 21 & & & & & & \\
\hline 1986 & 2799 & 78 & Questionnaire and $48 \mathrm{~h}$ recall (50\%) & & & 9) & $12\}$ & 15 & 18 & 21 & 24 & & & & & \\
\hline 1989 & $350 \dagger$ & 10 & Questionnaire & & & & 12) & 15 & 18 & 21 & 24 & 27 & & & & \\
\hline 1992 & $891 \dagger$ & 25 & Questionnaire & & & & & 15) & 18) & 21 & 24 & 27 & 30 & & & \\
\hline 2001 & 2620 & 73 & Questionnaire and $48 \mathrm{~h}$ recall (50\%) & & & & & & & & 24 & 27 & 30 & 33 & 36 & 39 \\
\hline
\end{tabular}

${ }^{\star}$ Bracketing around ages indicates the age groupings used.

† Measurements made only for subgroups. 
local food industry. Foreign food composition tables were used when no appropriate domestic data were available. After 1980 the food composition tables were passed to the responsibility of the National Public Health Institute. In 2001, the latest version of the National Food Composition Database was used to calculate the intakes of nutrients ${ }^{(33)}$. Ca intake that did not meet the Finnish nutrition recommendations was considered as inadequate (aged $6-9$ years $700 \mathrm{mg} / \mathrm{d} ; 10-18$ years $900 \mathrm{mg} / \mathrm{d}$; adults $800 \mathrm{mg} / \mathrm{d})^{(34)}$. The dietary data for adulthood in 2001 provide information on the food sources of nutrients, thus enabling us to calculate the subjects' intakes of Ca, lactose, protein and vitamin D separately from different types of milk products. The food composition table used in 2001 also allowed us to calculate the lactose content of different types of cultured milk products such as buttermilk, sour whole milk, yoghurt and curd cheese. Based on the dietary recall data, the lactose content of milk and milk products consumed was calculated as g lactose per $100 \mathrm{~g}$ milk and milk products consumed. This calculated variable was used as an indicator of preference for low-lactose milk and milk products and was divided into tertiles by sex in order to compare $\mathrm{Ca}$ intake between the tertiles. In females, the tertile limits were $(\mathrm{g} / 100 \mathrm{~g}$ milk products $)<3.2$ for low, $3.2-4.1$ for middle and $>4.1$ for high, and in males $<3.5,3.5-4.3$ and $>4 \cdot 3$, respectively.

\section{Lactase $C / T_{-13910}$ genotyping}

Blood samples were collected for genetic analysis in 2001. DNA was extracted from peripheral blood leucocytes with a commercially available kit (Qiagen Inc., Hilden, Germany). Lactase $\mathrm{C} / \mathrm{T}_{-13910}$ genotyping (rs4988235) was performed by employing a $5^{\prime}$-nuclease assay, and fluorogenic allelespecific TaqMan probes and primers ${ }^{(35)}$ were used with the ABI Prism 7000 Sequence Detection System (Applied Biosystems, Foster City, CA, USA). Known control samples were run in parallel with unknown DNA samples. Lactase $\mathrm{C} / \mathrm{T}_{-13910}$ polymorphism was measured in 2265 adults.

\section{Statistical analysis}

Statistical analyses were performed with SPSS 12.0 for Windows (SPSS Inc., Chicago, IL, USA). The Hardy-Weinberg equilibrium of the $\mathrm{C} / \mathrm{T}_{-13910}$ polymorphism was performed using the exact test of the Genepop software (http://wbiomed.curtin.edu.au/genepop) ${ }^{(36)}$. The homogeneity of variances across the lactase genotypes was tested with Levene's statistics. The differences in milk and milk product consumption and nutrient intakes from milk between the lactase genotypes were tested with one-way ANOVA, and for the variables with unequal variances with Kruskall-Wallis non-parametric analysis. Two-way ANOVA was used to analyse how the interaction between lactase genotype and lactose content of milk and milk products consumed was associated with daily $\mathrm{Ca}$ intake. With significant ANOVA $P$ values, Fisher's least significant difference method was used for pairwise post hoc comparisons, and the Bonferroni method was applied to non-significant $P$ values. If the Levene's test results were significant, we used the non-parametric Games-Howell post hoc test. Pearson's $\chi^{2}$ was used to compare the proportions of those with inadequate $\mathrm{Ca}$ intake with those with recommended $\mathrm{Ca}$ intake, milk drinkers with non-milk drinkers, and the proportions of those following a low-lactose or milk-free diet with those following a diet with normal lactose content within the lactase genotypes. Females and males were analysed separately and also pooled when $\mathrm{Ca}$ intake in adulthood was analysed. A $P$ value of less than 0.05 was considered significant.

\section{Results}

The distribution of lactase genotypes was in Hardy-Weinberg equilibrium $(P=0 \cdot 814)$ (Table 2$)$. Age, height, weight or energy intake in adulthood did not differ between the lactase genotypes in either sex (data not shown). When we compared milk and milk product consumption between the lactase genotypes, the most profound differences at all age points in both sexes were found in the consumption of milk (Table 2). Cheese consumption tended to be higher for the $\mathrm{C} / \mathrm{C}_{-13910}$ genotype, but the genotypes differed significantly only in 6-year-old males. The consumption of sour milk products did not differ between the lactase genotypes in either sex or at any age. The consumption of ice cream was so low that it was not included in the analyses.

In females, there was a trend of lower daily $\mathrm{Ca}$ and lactose intakes for the $\mathrm{C} / \mathrm{C}_{-13910}$ genotype since 9 years of age, although only $\mathrm{Ca}$ intake at the age of 9 years differed significantly between the genotypes (ANOVA $P=0.025, \mathrm{C} / \mathrm{C} v$. T/T $P=0.06$ and $\mathrm{C} / \mathrm{C} v . \mathrm{C} / \mathrm{T} P=0.007$ ) (Fig. 1). In males, a similar non-significant trend of difference in $\mathrm{Ca}$ and lactose intakes between the genotypes was found only at the age of 18 years. In adulthood, the $\mathrm{C} / \mathrm{C}_{-13910}$ genotype was associated with a lower daily $\mathrm{Ca}$ intake in both sexes (Table 3). However, the differences between the genotypes were significant only when the sexes were pooled (T/T $=1271 \mathrm{mg}$, $\mathrm{C} / \mathrm{T}=1322 \mathrm{mg}$ and $\mathrm{C} / \mathrm{C}=1167 \mathrm{mg} ;$ ANOVA $P=0.009$, $\mathrm{C} / \mathrm{C} v$. T/T $P=0.053$ and $\mathrm{C} / \mathrm{C} v . \mathrm{C} / \mathrm{T} P=0.002)$. In adulthood, daily lactose intake was lowest for the $\mathrm{C} / \mathrm{C}_{-13910}$ genotype in both sexes (Games-Howell: $\mathrm{C} / \mathrm{C} v . \mathrm{T} / \mathrm{T} P<0.001$ for females and $P=0.003$ for males, $\mathrm{C} / \mathrm{C} v$. C/T $P<0.001$ for both sexes). Adult females with the $\mathrm{C} / \mathrm{C}_{-13910}$ genotype had the lowest protein intake (Fisher's least significant difference: $\mathrm{C} / \mathrm{C} v . \mathrm{T} / \mathrm{T} P=0.37$ and $\mathrm{C} / \mathrm{C} v . \mathrm{C} / \mathrm{T} P=0.03)$. The daily intake of vitamin $\mathrm{D}$ in adulthood did not differ between the genotypes.

In adulthood, milk and milk products provided $72 \%$ of total $\mathrm{Ca}$ intake for the $\mathrm{T} / \mathrm{T}$ and $\mathrm{C} / \mathrm{T}_{-13910}$ genotypes and $68 \%$ for the $\mathrm{C} / \mathrm{C}_{-13910}$ genotype in females, and 72,76 and $70 \%$ for the genotypes $\mathrm{T} / \mathrm{T}, \mathrm{C} / \mathrm{T}$ and $\mathrm{C} / \mathrm{C}$ in males, respectively (for values, see Table 3). The intakes of $\mathrm{Ca}$, lactose, protein and vitamin $\mathrm{D}$ from milk were significantly lowest for the $\mathrm{C} / \mathrm{C}_{-13910}$ genotype in both sexes, but the intakes of these nutrients from cheese or sour milk products did not differ between the genotypes. In addition, the lactose content of milk and milk products consumed was lowest for those with the $\mathrm{C} / \mathrm{C}_{-13910}$ genotype; however, the difference was significant only in females (Fisher's least significant difference: $\mathrm{C} / \mathrm{C} v$. T/T $P=0.03$ and $\mathrm{C} / \mathrm{C} v$. $\mathrm{C} / \mathrm{T} P=0.001)$.

In females, the proportions of those with inadequate $\mathrm{Ca}$ intake were highest in the $\mathrm{C} / \mathrm{C}_{-13910}$ genotype at all ages (15-63\%); however, the differences were significant only at the ages of 9 and 15 years and in adulthood (Table 4). 
Table 2. Consumption of milk and milk products (dietary questionnaire) by age and lactase genotype

(Mean values and standard deviations)

\begin{tabular}{|c|c|c|c|c|c|c|c|c|c|c|c|c|c|c|c|c|}
\hline \multirow{3}{*}{ Lactase genotype. . } & \multirow[b]{3}{*}{ Subjects $(n)$} & \multicolumn{6}{|c|}{ Females } & \multirow[b]{3}{*}{$P^{*}$} & \multirow[b]{3}{*}{ Subjects $(n)$} & \multicolumn{6}{|c|}{ Males } & \multirow[b]{3}{*}{$P^{\star}$} \\
\hline & & \multicolumn{2}{|c|}{$T / T$} & \multicolumn{2}{|c|}{$\mathrm{C} / \mathrm{T}$} & \multicolumn{2}{|c|}{$\mathrm{C} / \mathrm{C}$} & & & \multicolumn{2}{|c|}{$T / T$} & \multicolumn{2}{|c|}{$\mathrm{C} / \mathrm{T}$} & \multicolumn{2}{|c|}{$\mathrm{C} / \mathrm{C}$} & \\
\hline & & Mean & SD & Mean & SD & Mean & SD & & & Mean & SD & Mean & SD & Mean & SD & \\
\hline Genotype distribution $(n)$ & & \multicolumn{2}{|c|}{425} & \multicolumn{2}{|c|}{616} & \multicolumn{2}{|c|}{215} & & & \multicolumn{2}{|c|}{339} & \multicolumn{2}{|c|}{500} & \multicolumn{2}{|c|}{186} & \\
\hline Genotype distribution (\%) & & \multicolumn{2}{|c|}{34} & & & \multicolumn{2}{|c|}{17} & & & \multicolumn{2}{|c|}{33} & & & \multicolumn{2}{|c|}{18} & \\
\hline \multicolumn{17}{|l|}{ Milk index (portions/d)† } \\
\hline 6 years & 317 & $4 \cdot 2$ & 1.5 & 4.7 & 1.4 & 3.7 & 1.4 & $<0.001$ & 244 & 4.9 & 1.8 & 4.5 & $1 \cdot 6$ & 4.5 & 1.7 & 0.31 \\
\hline 9 years & 529 & 4.3 & 1.6 & 4.5 & 1.6 & 4.0 & 1.5 & 0.07 & 426 & $5 \cdot 2$ & 1.8 & 4.5 & 1.7 & $4 \cdot 7$ & 1.6 & 0.001 \\
\hline 12 years & 702 & 4.5 & 1.7 & 4.6 & 1.8 & 3.9 & 1.9 & 0.002 & 564 & $5 \cdot 2$ & 1.9 & 4.9 & $2 \cdot 0$ & 4.7 & $2 \cdot 3$ & 0.17 \\
\hline 15 years & 767 & $4 \cdot 1$ & $2 \cdot 0$ & 3.9 & 1.7 & 3.8 & 1.9 & 0.37 & 592 & $5 \cdot 3$ & $2 \cdot 1$ & $5 \cdot 2$ & $2 \cdot 2$ & 4.6 & $2 \cdot 1$ & 0.012 \\
\hline 18 years & 710 & $3 \cdot 3$ & $1 \cdot 6$ & $3 \cdot 2$ & 1.5 & $2 \cdot 9$ & $1 \cdot 6$ & 0.12 & 558 & $5 \cdot 3$ & $2 \cdot 3$ & 4.9 & $2 \cdot 3$ & 4.8 & $2 \cdot 0$ & 0.08 \\
\hline Adult (24-39 years) & 1256 & $2 \cdot 7$ & 1.7 & $2 \cdot 7$ & 1.6 & $2 \cdot 2$ & $1 \cdot 3$ & $<0.001 \ddagger$ & 1025 & 3.5 & $2 \cdot 1$ & 3.4 & $2 \cdot 1$ & $2 \cdot 6$ & 1.7 & $<0.001 \ddagger$ \\
\hline Milk (glasses/d) & & & & & & & & & & & & & & & & \\
\hline 6 years & 317 & $3 \cdot 0$ & 1.4 & 3.4 & 1.4 & $2 \cdot 7$ & 1.4 & 0.001 & 244 & 3.7 & 1.7 & $3 \cdot 3$ & 1.5 & $3 \cdot 3$ & 1.7 & 0.2 \\
\hline 9 years & 529 & $3 \cdot 1$ & 1.6 & 3.3 & 1.6 & $2 \cdot 9$ & 1.5 & 0.14 & 426 & 4.0 & 1.7 & 3.4 & 1.7 & 3.4 & 1.6 & 0.001 \\
\hline 12 years & 702 & $3 \cdot 3$ & $1 \cdot 7$ & 3.4 & 1.8 & $2 \cdot 7$ & 1.8 & 0.001 & 564 & 4.0 & 1.8 & 3.8 & $2 \cdot 0$ & 3.5 & $2 \cdot 1$ & $0.02 \ddagger$ \\
\hline 15 years & 767 & 3.0 & 1.9 & $2 \cdot 9$ & 1.7 & $2 \cdot 6$ & $2 \cdot 0$ & $0 \cdot 11$ & 592 & 4.2 & $2 \cdot 1$ & 4.0 & $2 \cdot 1$ & 3.5 & $2 \cdot 1$ & 0.01 \\
\hline 18 years & 710 & $2 \cdot 4$ & 1.7 & $2 \cdot 2$ & 1.6 & 1.8 & 1.5 & 0.001 & 558 & $4 \cdot 2$ & $2 \cdot 3$ & 4.0 & $2 \cdot 4$ & 3.7 & $2 \cdot 2$ & 0.17 \\
\hline Adult (24-39 years) & 1256 & 1.4 & $1 \cdot 6$ & 1.5 & 1.5 & 0.8 & $1 \cdot 3$ & $<0.001 \ddagger$ & 1025 & $2 \cdot 3$ & $2 \cdot 0$ & $2 \cdot 2$ & $2 \cdot 1$ & 1.5 & $1 \cdot 7$ & $<0.001 \ddagger$ \\
\hline Cheese (portions/week) & & & & & & & & & & & & & & & & \\
\hline 6 years & 317 & $3 \cdot 6$ & $2 \cdot 5$ & 3.8 & $2 \cdot 4$ & $3 \cdot 1$ & $2 \cdot 3$ & 0.14 & 244 & $3 \cdot 2$ & $2 \cdot 6$ & $3 \cdot 8$ & $2 \cdot 6$ & 4.5 & $2 \cdot 4$ & 0.02 \\
\hline 9 years & 529 & $3 \cdot 8$ & $2 \cdot 6$ & $4 \cdot 0$ & $2 \cdot 6$ & $4 \cdot 0$ & $2 \cdot 4$ & 0.76 & 426 & 3.6 & $2 \cdot 8$ & $3 \cdot 8$ & $2 \cdot 6$ & 3.9 & $2 \cdot 9$ & 0.55 \\
\hline 12 years & 702 & 4.0 & 2.5 & $4 \cdot 3$ & 2.5 & 4.5 & $2 \cdot 4$ & 0.15 & 564 & $3 \cdot 8$ & $2 \cdot 8$ & $3 \cdot 8$ & $2 \cdot 6$ & 4.4 & $2 \cdot 6$ & 0.1 \\
\hline 15 years & 767 & 3.9 & $2 \cdot 4$ & 3.8 & 2.4 & 3.6 & $2 \cdot 4$ & 0.4 & 592 & 3.8 & $2 \cdot 7$ & 3.9 & $2 \cdot 4$ & 3.8 & $2 \cdot 7$ & $0.87 \ddagger$ \\
\hline 18 years & 710 & 3.9 & $2 \cdot 5$ & $4 \cdot 1$ & 2.4 & $4 \cdot 2$ & 2.5 & 0.62 & 558 & $4 \cdot 0$ & $2 \cdot 6$ & 3.9 & $2 \cdot 7$ & 3.9 & $2 \cdot 5$ & 0.99 \\
\hline Adult (24-39 years) & 1256 & 4.9 & $2 \cdot 8$ & 4.8 & $2 \cdot 8$ & $5 \cdot 2$ & $2 \cdot 7$ & 0.17 & 1025 & 4.5 & $2 \cdot 9$ & 4.8 & $2 \cdot 8$ & 4.9 & $2 \cdot 4$ & 0.11 \\
\hline Sour milk products (portic & week) & & & & & & & & & & & & & & & \\
\hline 6 years & 317 & $3 \cdot 7$ & $2 \cdot 4$ & $3 \cdot 8$ & $2 \cdot 6$ & $3 \cdot 2$ & 2.5 & 0.27 & 244 & $3 \cdot 6$ & 2.5 & 3.8 & $2 \cdot 5$ & 3.4 & $2 \cdot 4$ & 0.52 \\
\hline 9 years & 529 & $3 \cdot 7$ & $2 \cdot 7$ & 3.7 & $2 \cdot 6$ & $3 \cdot 2$ & $2 \cdot 8$ & 0.29 & 426 & 3.6 & $2 \cdot 6$ & 3.4 & $2 \cdot 5$ & 3.8 & $2 \cdot 9$ & $0.60 \ddagger$ \\
\hline 12 years & 702 & 3.4 & 2.5 & $3 \cdot 3$ & $2 \cdot 6$ & $3 \cdot 2$ & 2.5 & 0.77 & 564 & 3.5 & $2 \cdot 7$ & 3.4 & $2 \cdot 6$ & 3.4 & $2 \cdot 6$ & 0.98 \\
\hline 15 years & 767 & $2 \cdot 8$ & $2 \cdot 4$ & $2 \cdot 7$ & $2 \cdot 4$ & $2 \cdot 6$ & $2 \cdot 4$ & 0.8 & 592 & 3.0 & $2 \cdot 6$ & $2 \cdot 8$ & $2 \cdot 4$ & 3.0 & $2 \cdot 6$ & 0.76 \\
\hline 18 years & 710 & $2 \cdot 8$ & 2.5 & $2 \cdot 9$ & $2 \cdot 6$ & $2 \cdot 7$ & 2.5 & 0.66 & 558 & $3 \cdot 1$ & $2 \cdot 6$ & $2 \cdot 7$ & $2 \cdot 6$ & 2.5 & $2 \cdot 4$ & 0.14 \\
\hline Adult (24-39 years) & 1256 & 3.5 & $2 \cdot 4$ & 3.4 & 2.5 & 3.4 & $2 \cdot 4$ & 0.8 & 1025 & $2 \cdot 8$ & $2 \cdot 4$ & $2 \cdot 9$ & 2.5 & 2.5 & $2 \cdot 4$ & $0.08 \ddagger$ \\
\hline
\end{tabular}

*One-way ANOVA.

† Reported frequency of consumption of milk and milk products (portions/d).

$\ddagger$ Kruskall-Wallis non-parametric test. 

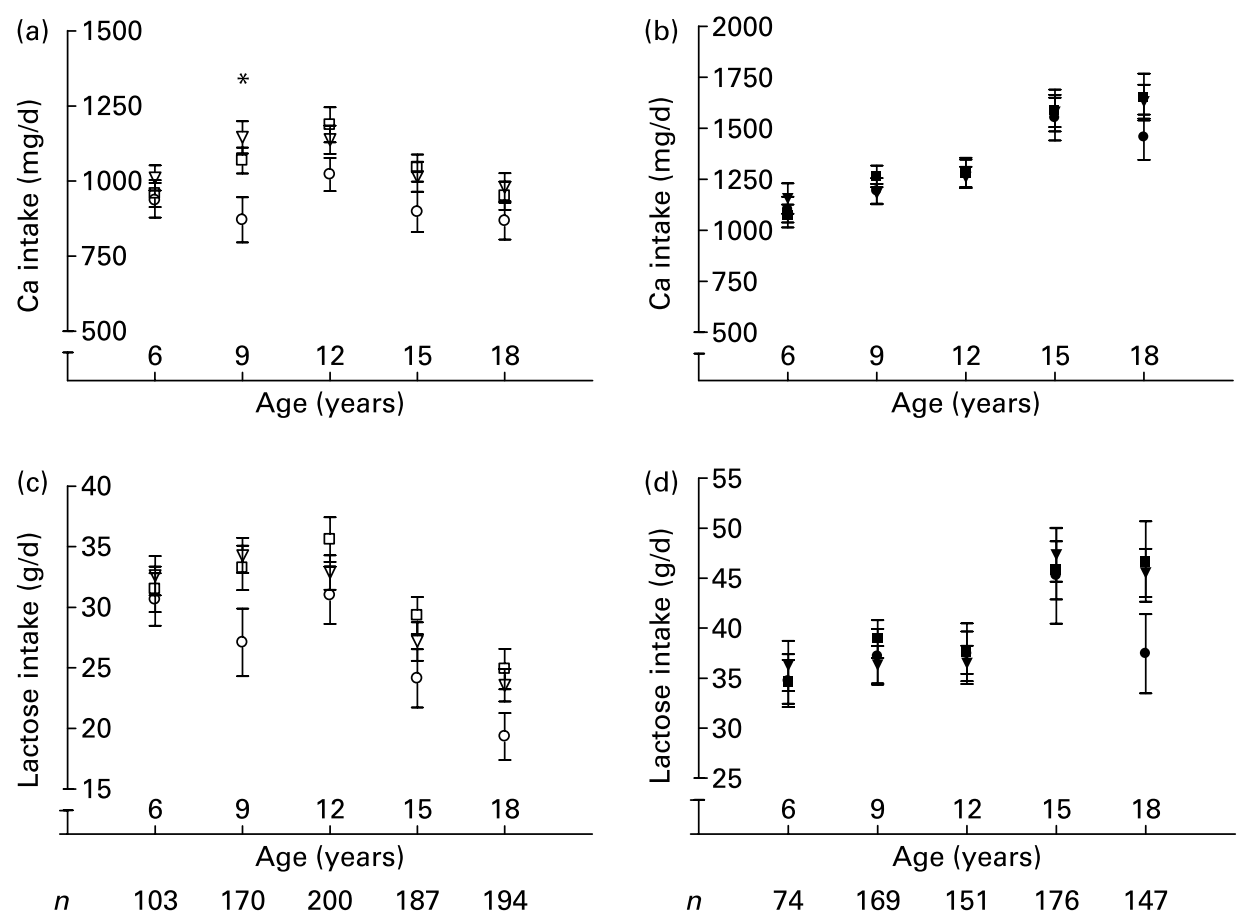

Fig. 1. Intakes of (a) Ca in females ( $\mathrm{mg} / \mathrm{d})$, (b) $\mathrm{Ca}$ in males, (c) lactose in females ( $\mathrm{g} / \mathrm{d})$ and (d) lactose in males in relation to age by the lactase genotypes: in females T/T $(\square)$; C/T $(\nabla) ; \mathrm{C} / \mathrm{C}(\mathrm{O})$ and in males $\mathrm{T} / \mathrm{T}(\mathbf{\square}) ; \mathrm{C} / \mathrm{T}(\mathbf{\nabla}) ; \mathrm{C} / \mathrm{C}(\bullet)$. Lactose and $\mathrm{Ca}$ intakes were assessed with a detailed $48 \mathrm{~h}$ dietary recall. Values are means, with standard errors represented by vertical bars. ${ }^{*} \mathrm{Ca}$ intake in 9-year-old females differed between the lactase genotypes: ANOVA $P=0.025, \mathrm{C} / \mathrm{C} v$. T/T $P=0.06$ and $\mathrm{C} / \mathrm{C} v . \mathrm{C} / \mathrm{T} P=0.007$.

In males, inadequate $\mathrm{Ca}$ intake was more common in the $\mathrm{C} / \mathrm{C}_{-13910}$ genotype $(24 \%)$ than in other genotypes only in adulthood. The proportions of those who reported not drinking milk were highest in adulthood, being over half in females and over one-third in males with the $\mathrm{C} / \mathrm{C}_{-13910}$ genotype. In adulthood, those with the $\mathrm{C} / \mathrm{C}_{-13910}$ genotype reported following low-lactose or milk-free diets more often than did those with $\mathrm{C} / \mathrm{T}$ or $\mathrm{T} / \mathrm{T}_{-13910}$ genotypes. In both sexes, the avoidance of lactose and milk increased with age in all lactase genotypes.

In both sexes, those in the lowest lactose content tertile consumed more cheese and sour milk products and less milk than those in the second and third tertiles (Table 5). Adult females with the $\mathrm{C} / \mathrm{C}_{-13910}$ genotype who consumed milk and milk products with higher lactose content had lower $\mathrm{Ca}$ intake than those in other genotypes (genotype $\times$ lactose content of milk products consumed $P=0.022$ ) (Fig. 2). In lower lactose content tertiles, $\mathrm{Ca}$ intake did not differ between the lactase genotypes. In males, the trend was similar but not significant (genotype $\times$ lactose content of milk products consumed $P=0 \cdot 136)$.

\section{Discussion}

The primary aim of the present study was to investigate the differences in milk and milk product consumption and nutrient intakes from milk and milk products between the lactase genotypes, since previous evidence is neither comprehensive nor consistent $^{(15-17,20-25)}$. Furthermore, this is the first study to examine the differences in the type of milk products consumed and in the lactose intake between the lactase genotypes in a follow-up setting from childhood into adulthood.
We showed that already in childhood, those with the $\mathrm{C} / \mathrm{C}_{-13910}$ genotype consumed less milk than did those with the other genotypes, and the proportions of those not drinking milk were greatest in the $\mathrm{C} / \mathrm{C}_{-13910}$ genotype as early as in childhood. These results are in congruence with earlier findings from Finnish studies ${ }^{(20,21)}$. In addition, those with the $\mathrm{C} / \mathrm{C}_{-13910}$ genotype tended to eat more cheese than did those with other genotypes, although the differences were not significant and not distinct at all age points. We found no differences in the habitual consumption of sour milk products between the lactase genotypes, although lactose maldigesters do tolerate fermented milk products better than nonfermented $^{(37)}$. It is noteworthy that until the age of 12 years, the consumption of milk and milk products in males with the $\mathrm{C} / \mathrm{C}$ and $\mathrm{C} / \mathrm{T}_{-13910}$ genotypes was very similar and lower than for the $\mathrm{T} / \mathrm{T}-13910$ genotype. In females with the $\mathrm{C} / \mathrm{C}_{-13910}$ genotype milk and milk product consumption was lowest since the age of 6 years. These findings could result from sex differences in the manifestation age of genetic lactase non-persistence or in the magnitude of the $T_{-13910}$ variant expression, but evidence is lacking. One possible explanation could be that females and males differ in their sensitivity to gastrointestinal symptoms caused by maldigested lactose. Previous studies have shown that women with lactose maldigestion may experience stronger symptoms than men with lactose maldigestion ${ }^{(38,39)}$. The present results support these findings because low-lactose or milk-free diets were almost twice as common in females with the $\mathrm{C} / \mathrm{C}_{-13910}$ genotype than in males with the same genotype.

A glass of milk or sour milk is a typical meal component in Finland both for children and adults. In addition, milk products are commonly used as components of traditional Finnish 
Table 3. Dietary intakes of selected nutrients ( $48 \mathrm{~h}$ dietary recall) in adulthood (24-39 years) by lactase genotype (Mean values and standard deviations)

\begin{tabular}{|c|c|c|c|c|c|c|c|c|c|c|c|c|c|c|}
\hline \multirow{3}{*}{ Lactase genotype... } & \multicolumn{6}{|c|}{ Females } & \multirow[b]{3}{*}{$P^{*}$} & \multicolumn{6}{|c|}{ Males } & \multirow[b]{3}{*}{$P^{*}$} \\
\hline & \multicolumn{2}{|c|}{$\mathrm{T} / \mathrm{T}$} & \multicolumn{2}{|c|}{$\mathrm{C} / \mathrm{T}$} & \multicolumn{2}{|c|}{$\mathrm{C} / \mathrm{C}$} & & \multicolumn{2}{|c|}{$\mathrm{T} / \mathrm{T}$} & \multicolumn{2}{|c|}{$\mathrm{C} / \mathrm{T}$} & \multicolumn{2}{|c|}{$\mathrm{C} / \mathrm{C}$} & \\
\hline & Mean & SD & Mean & SD & Mean & SD & & Mean & SD & Mean & SD & Mean & SD & \\
\hline Subjects $(n)$ & \multicolumn{2}{|c|}{193} & \multicolumn{2}{|c|}{273} & \multicolumn{2}{|c|}{100} & & \multicolumn{2}{|c|}{152} & \multicolumn{2}{|c|}{232} & \multicolumn{2}{|c|}{81} & \\
\hline Subjects (\%) & \multirow{2}{*}{\multicolumn{2}{|c|}{34}} & & & \multirow{2}{*}{\multicolumn{2}{|c|}{18}} & & \multirow{2}{*}{\multicolumn{2}{|c|}{33}} & & & \multirow{2}{*}{\multicolumn{2}{|c|}{17}} & \\
\hline \multicolumn{7}{|l|}{ Ca intake $(\mathrm{mg} / \mathrm{d})$} & & & & & & & & \\
\hline All sources & 1160 & 470 & 1174 & 479 & 1048 & 462 & 0.07 & 1413 & 727 & 1497 & 661 & 1313 & 563 & 0.09 \\
\hline Milk products as sources of $\mathrm{Ca}$ & 886 & 468 & 889 & 466 & 766 & 447 & 0.06 & 1100 & 696 & 1183 & 634 & 992 & 537 & 0.06 \\
\hline Milk & 332 & 321 & 361 & 300 & 215 & 229 & $<0.001 \dagger$ & 523 & 467 & 553 & 517 & 351 & 305 & $0.009 \dagger$ \\
\hline Cheese & 382 & 306 & 371 & 322 & 376 & 326 & 0.93 & 438 & 412 & 476 & 376 & 524 & 397 & 0.28 \\
\hline Sour milk products & 143 & 156 & 128 & 162 & 149 & 178 & 0.44 & 111 & 176 & 124 & 220 & 92 & 141 & 0.41 \\
\hline \multicolumn{15}{|l|}{ Lactose intake $(\mathrm{g} / \mathrm{d})$} \\
\hline All sources & $18 \cdot 8$ & $13 \cdot 2$ & $19 \cdot 3$ & $13 \cdot 3$ & $13 \cdot 1$ & $9 \cdot 8$ & $<0.001 \dagger$ & 26 & $19 \cdot 9$ & $28 \cdot 1$ & 21.5 & $18 \cdot 7$ & $13 \cdot 1$ & $0.003 \dagger$ \\
\hline Milk products as sources of lactose & $17 \cdot 6$ & $13 \cdot 2$ & $18 \cdot 3$ & $13 \cdot 1$ & 12 & 9.5 & $<0.001 \dagger$ & $24 \cdot 7$ & $19 \cdot 8$ & $26 \cdot 5$ & 21.3 & $17 \cdot 3$ & $12 \cdot 7$ & $0.003 \dagger$ \\
\hline Milk & $13 \cdot 3$ & $23 \cdot 2$ & 14.4 & $12 \cdot 6$ & 8 & 8.92 & $<0.001 \dagger$ & $21 \cdot 3$ & $19 \cdot 1$ & $22 \cdot 7$ & $21 \cdot 2$ & 14.4 & 13 & $0.006 \dagger$ \\
\hline Cheese & 0.2 & 0.44 & 0.19 & 0.54 & 0.17 & 0.38 & 0.86 & 0.2 & 0.49 & 0.12 & 0.31 & 0.14 & 0.38 & 0.13 \\
\hline Sour milk products & 3.15 & 3.87 & $2 \cdot 65$ & 3.71 & $2 \cdot 91$ & 3.95 & 0.38 & $2 \cdot 13$ & 3.33 & $2 \cdot 65$ & $5 \cdot 21$ & 1.86 & $2 \cdot 9$ & 0.29 \\
\hline Lactose content of milk products $(\mathrm{g} / 100 \mathrm{~g}) \ddagger$ & 3.44 & 1.09 & 3.6 & 1.03 & $3 \cdot 16$ & $1 \cdot 15$ & 0.003 & $3 \cdot 72$ & 1.03 & 3.74 & 1.06 & $3 \cdot 44$ & $1 \cdot 14$ & 0.09 \\
\hline \multicolumn{15}{|l|}{ Protein intake $(g / d)$} \\
\hline Milk products as sources of protein & $24 \cdot 7$ & $13 \cdot 2$ & 24.9 & 12.9 & $21 \cdot 2$ & 12 & 0.012 & $30 \cdot 6$ & 19 & 32.5 & 17.4 & $28 \cdot 2$ & $15 \cdot 7$ & 0.15 \\
\hline Milk & 8.69 & 8.39 & 9.42 & 7.79 & 5.59 & 5.92 & $<0.001 \dagger$ & 13.7 & $12 \cdot 1$ & 14.5 & 13.5 & $9 \cdot 2$ & 8.03 & $0.010 \dagger$ \\
\hline Cheese & 11.7 & 9.54 & 11.5 & 9.87 & 11.3 & 9.06 & 0.94 & 13.4 & 11.8 & $14 \cdot 2$ & $10 \cdot 9$ & $15 \cdot 9$ & $12 \cdot 3$ & 0.28 \\
\hline Sour milk products & 3.6 & 3.83 & $3 \cdot 24$ & 3.72 & 3.72 & 4.47 & 0.47 & 2.78 & 4.46 & 3.15 & 5.58 & $2 \cdot 38$ & 3.62 & 0.45 \\
\hline \multicolumn{15}{|l|}{ Vitamin $D$ intake $(\mu \mathrm{g} / \mathrm{d})$} \\
\hline All sources & 3.69 & 3.48 & 4.94 & $19 \cdot 3$ & 3.3 & 2.58 & 0.47 & $5 \cdot 61$ & 6.91 & 4.76 & 4.49 & 4.2 & $3 \cdot 15$ & $0.86 \dagger$ \\
\hline Milk products as sources of vitamin D & 0.35 & 0.23 & 0.38 & 0.24 & 0.3 & 0.2 & 0.043 & 0.49 & 0.38 & 0.51 & 0.39 & 0.34 & 0.23 & $0.005 \dagger$ \\
\hline Milk & 0.19 & 0.21 & 0.21 & 0.22 & $0 \cdot 13$ & 0.17 & $<0.001 \dagger$ & 0.31 & 0.35 & 0.32 & 0.38 & $0 \cdot 17$ & 0.18 & $0.003 \dagger$ \\
\hline Cheese & 0.09 & 0.08 & 0.09 & 0.08 & 0.09 & 0.08 & 0.9 & $0 \cdot 11$ & 0.1 & 0.11 & 0.09 & $0 \cdot 13$ & 0.1 & 0.29 \\
\hline Sour milk products & 0.05 & 0.07 & 0.05 & 0.09 & 0.06 & 0.09 & 0.59 & 0.04 & $0 \cdot 1$ & 0.05 & 0.11 & 0.02 & 0.05 & 0.2 \\
\hline
\end{tabular}

*One-way ANOVA.

non-parametric test.

$\ddagger$ The lactose content of milk products was calculated as $\mathrm{g}$ lactose per $100 \mathrm{~g}$ milk and milk products consumed. 
Table 4. The numbers and proportions (\%) of those who have inadequate Ca intake, who do not drink milk or who report following a low-lactose or milk-free diet by lactase genotype

\begin{tabular}{|c|c|c|c|c|c|c|c|c|c|c|c|c|c|c|}
\hline & \multicolumn{7}{|c|}{ Females } & \multicolumn{7}{|c|}{ Males } \\
\hline & \multicolumn{2}{|c|}{$\mathrm{T} / \mathrm{T}$} & \multicolumn{2}{|c|}{$\mathrm{C} / \mathrm{T}$} & \multicolumn{2}{|c|}{$\mathrm{C} / \mathrm{C}$} & \multirow{2}{*}{$\begin{array}{c}\chi^{2} \text { test } \\
P\end{array}$} & \multicolumn{2}{|c|}{$\mathrm{T} / \mathrm{T}$} & \multicolumn{2}{|c|}{$\mathrm{C} / \mathrm{T}$} & \multicolumn{2}{|c|}{$\mathrm{C} / \mathrm{C}$} & \multirow{2}{*}{$\begin{array}{c}\chi^{2} \text { test } \\
P\end{array}$} \\
\hline & $n / N$ & $\%$ & $n / N$ & $\%$ & $n / N$ & $\%$ & & $n / N$ & $\%$ & $n / N$ & $\%$ & $n / N$ & $\%$ & \\
\hline \multicolumn{15}{|c|}{ Ca intake lower than recommended ${ }^{\star}$} \\
\hline 6 years & $4 / 33$ & 12 & $7 / 50$ & 14 & $3 / 20$ & 15 & 0.95 & $3 / 23$ & 13 & $5 / 35$ & 14 & $1 / 16$ & 6 & 0.71 \\
\hline 9 years & $11 / 62$ & 18 & $17 / 85$ & 20 & $10 / 23$ & 44 & 0.03 & $4 / 63$ & 6 & $12 / 80$ & 5 & $2 / 26$ & 8 & 0.22 \\
\hline 12 years & $15 / 60$ & 25 & $36 / 107$ & 34 & 9/33 & 27 & 0.47 & $8 / 48$ & 17 & $13 / 67$ & 19 & $10 / 36$ & 28 & 0.44 \\
\hline 15 years & $28 / 71$ & 39 & $34 / 86$ & 40 & $19 / 30$ & 63 & 0.05 & $10 / 59$ & 17 & $7 / 89$ & 8 & $3 / 28$ & 11 & 0.23 \\
\hline 18 years & $28 / 61$ & 46 & $48 / 96$ & 50 & $22 / 36$ & 61 & 0.34 & $6 / 46$ & 13 & $12 / 78$ & 15 & $2 / 23$ & 9 & 0.71 \\
\hline Adult (24-39 years) & $44 / 193$ & 23 & $58 / 273$ & 21 & $36 / 100$ & 36 & 0.01 & $27 / 152$ & 18 & $23 / 231$ & 10 & $19 / 81$ & 24 & 0.006 \\
\hline \multicolumn{15}{|l|}{ Does not drink milk† } \\
\hline 6 years & $7 / 115$ & 6 & $2 / 167$ & 1 & $6 / 56$ & 11 & 0.006 & $1 / 90$ & 1 & $7 / 129$ & 5 & $5 / 44$ & 11 & 0.03 \\
\hline 9 years & $12 / 194$ & 6 & $26 / 273$ & 6 & $8 / 78$ & 10 & 0.37 & $5 / 151$ & 3 & $21 / 191$ & 10 & $3 / 85$ & 3 & 0.02 \\
\hline 12 years & $19 / 251$ & 8 & $23 / 367$ & 6 & $20 / 116$ & 17 & 0.001 & $11 / 196$ & 6 & $22 / 296$ & 7 & $10 / 115$ & 9 & 0.56 \\
\hline 15 years & $39 / 321$ & 12 & $49 / 456$ & 11 & $26 / 155$ & 17 & 0.14 & $12 / 252$ & 5 & $24 / 363$ & 7 & $13 / 138$ & 9 & 0.20 \\
\hline 18 years & $52 / 299$ & 17 & $78 / 449$ & 17 & $37 / 153$ & 24 & 0.14 & $15 / 235$ & 6 & $22 / 333$ & 7 & $10 / 117$ & 9 & 0.73 \\
\hline Adult (24-39 years) & $168 / 425$ & 40 & $219 / 616$ & 36 & $118 / 215$ & 55 & $<0.001$ & $80 / 339$ & 24 & $144 / 500$ & 29 & $71 / 186$ & 38 & 0.002 \\
\hline \multicolumn{15}{|c|}{ Low-lactose or milk-free diet } \\
\hline 6 years & $0 / 47$ & 0 & $0 / 70$ & 0 & $0 / 30$ & 0 & - & 0/71 & 0 & $0 / 106$ & 0 & $0 / 37$ & 0 & - \\
\hline 9 years & $0 / 123$ & 0 & $0 / 184$ & 0 & $0 / 39$ & 0 & - & $0 / 118$ & 0 & $2 / 158$ & 1 & $1 / 70$ & 1 & 0.45 \\
\hline 12 years & $0 / 167$ & 0 & $2 / 247$ & 1 & $1 / 85$ & 1 & 0.44 & $0 / 171$ & 0 & $0 / 248$ & 0 & $1 / 93$ & 1 & 0.11 \\
\hline 15 years & $0 / 214$ & 0 & $2 / 301$ & 1 & $1 / 104$ & 1 & 0.42 & $0 / 227$ & 0 & $3 / 316$ & 0.9 & $2 / 123$ & 2 & 0.21 \\
\hline 18 years & $0 / 103$ & 0 & $3 / 147$ & 2 & $1 / 58$ & 2 & 0.36 & 0/102 & 0 & $0 / 155$ & 0 & $1 / 55$ & 2 & 0.45 \\
\hline Adult (24-39 years) & 20/309 & 7 & $29 / 453$ & 6 & $34 / 152$ & 22 & $<0.001$ & $15 / 276$ & 5 & $24 / 420$ & 6 & $21 / 171$ & 12 & 0.009 \\
\hline
\end{tabular}

*Finnish Nutrition Recommendations ${ }^{(34)}$ for Ca intake: children 6-9 years, $700 \mathrm{mg} / \mathrm{d}$; children and adolescents of $10-20$ years, $900 \mathrm{mg} / \mathrm{d}$; adults, $800 \mathrm{mg} / \mathrm{d}$.

†The questionnaire of dietary habits included a question on how many glasses of milk the subjects drink daily, and those who reported none were classified as not drinking milk.

$\ddagger$ The questionnaire of dietary habits included a question on whether subjects followed a diet with low lactose content or a milk-free diet

dishes such as soups, porridges and desserts. In Finland, unlike in most European countries, low-lactose milk and milk products have been on the market and in common use since the 1980s. Wide selections of low-lactose milks, sour milks, yoghurts and other milk products are available in most grocery stores at affordable prices. Because many Finns are aware of lactose non-persistence and familiar with low-lactose milk and milk products, these products are also widely used in institutional kitchens, restaurants, cafés and by the food industry. Therefore, it was expected that those with the $\mathrm{C} / \mathrm{C}_{-13910}$ genotype followed low-lactose or milk-free diets more often than those with lactase persistence genotypes. The avoidance of milk and lactose in the diet was more common in the $\mathrm{C} / \mathrm{C}_{-13910}$ genotype in adulthood than in childhood and adolescence, although previous findings from Finnish studies suggest that in the majority of children aged 8 years and in all children older than 12 years, the $\mathrm{C} / \mathrm{C}_{-13910}$ genotype was already associated with very low lactase activity $(<10 \mathrm{U} / \mathrm{g}$ protein) and lower milk consumption ${ }^{(20)}$. Furthermore, the lactose content of milk and milk products chosen was lowest in females with the $\mathrm{C} / \mathrm{C}_{-13910}$ genotype and in males the difference between genotypes was borderline significant. Nevertheless, the proportion of those not drinking milk and those who followed a low-lactose diet increased with age in all lactase genotypes in both sexes, which is in congruence with other studies showing a poor correlation between genetically confirmed lactase non-persistence and self-reported lactose intolerance $^{(16,23)}$. However, in Finland, the consumption of milk has decreased over the past decades, and simultaneously the consumption of other milk products has increased ${ }^{(19)}$, which explains why the proportion of milk drinkers decreased among all genotypes. In adulthood, the proportions of those not drinking milk were higher than proportions of those following low-lactose or milk-free diets. This finding could be

Table 5. Milk product consumption in the tertiles of lactose content in milk products consumed (Mean values and standard deviations)

\begin{tabular}{|c|c|c|c|c|c|c|c|c|c|c|c|c|}
\hline \multirow{3}{*}{$\begin{array}{l}\text { Tertiles of lactose content in milk } \\
\text { products consumed }(\mathrm{g} / 100 \mathrm{~g})\end{array}$} & \multicolumn{6}{|c|}{ Female ( $n$ 544) } & \multicolumn{6}{|c|}{ Male ( $n$ 443) } \\
\hline & \multicolumn{2}{|c|}{1 st $<3 \cdot 2$} & \multicolumn{2}{|c|}{ 2nd $3 \cdot 2-4 \cdot 1$} & \multicolumn{2}{|c|}{$3 r d>4.1$} & \multicolumn{2}{|c|}{1 st $<3.5$} & \multicolumn{2}{|c|}{ 2nd $3.5-4.3$} & \multicolumn{2}{|c|}{$3 r d>4.3$} \\
\hline & Mean & SD & Mean & SD & Mean & SD & Mean & SD & Mean & SD & Mean & SD \\
\hline Cheese (portions/d) $)^{\star \star \star}$ & 0.77 & 0.39 & 0.73 & 0.38 & 0.61 & 0.39 & 0.80 & 0.35 & 0.64 & 0.41 & 0.62 & 0.39 \\
\hline Sour milk products (portions/d) ${ }^{\star \star *}$ & 0.55 & 0.36 & 0.52 & 0.33 & 0.41 & 0.34 & 0.46 & 0.36 & 0.45 & 0.36 & 0.29 & 0.29 \\
\hline Milk (portions/d) ${ }^{\star \star \star}$ & 0.43 & 0.90 & 1.36 & $1 \cdot 28$ & $2 \cdot 27$ & 1.76 & 0.76 & $1 \cdot 12$ & $2 \cdot 19$ & 1.66 & 3.41 & 2.05 \\
\hline
\end{tabular}

${ }^{* \star *} P<0.001$ for both sexes (ANOVA). 


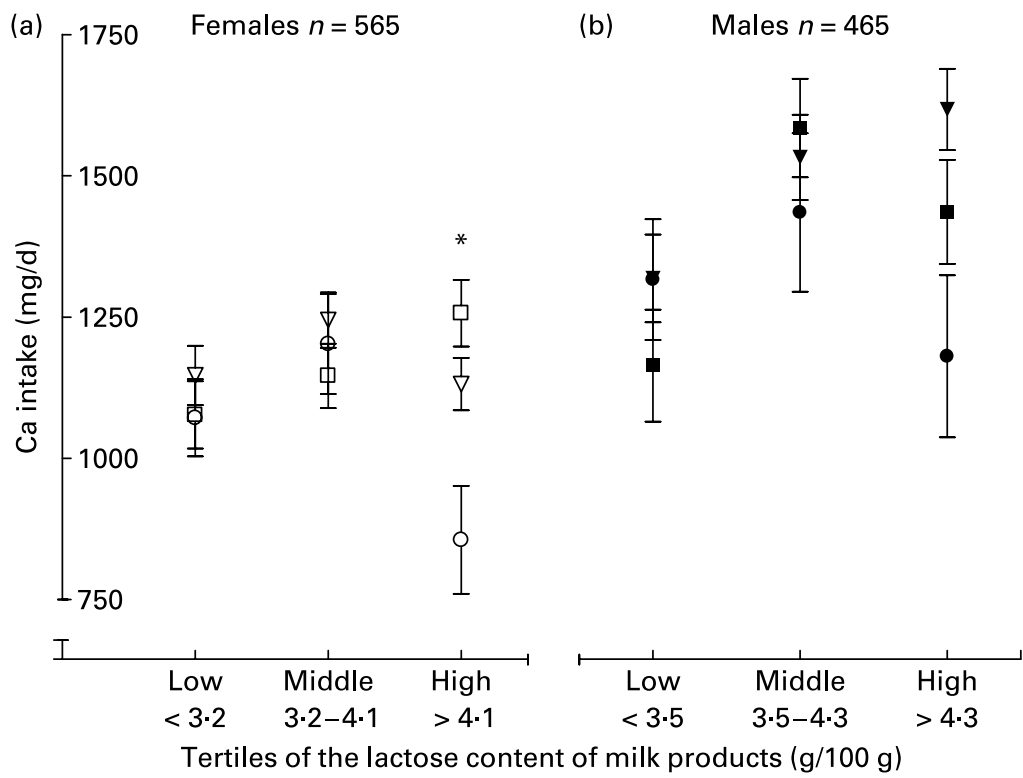

Fig. 2. (a) Ca intake in tertiles of the lactose content of milk and milk products consumed in adult females ( $n$ 565) (age range $24-39$ years) by lactase genotypes: $\mathrm{T} / \mathrm{T}(\square) ; \mathrm{C} / \mathrm{T}(\nabla) ; \mathrm{C} / \mathrm{C}(\mathrm{O})$. (b) Ca intake in tertiles of the lactose content of milk and milk products consumed in adult males ( $n$ 465) (age range 24-39 years) by lactase genotypes: $\mathrm{T} / \mathrm{T}(\mathbf{\square}) ; \mathrm{C} / \mathrm{T}(\mathbf{\nabla}) ; \mathrm{C} / \mathrm{C}(\bullet)$. Data on $\mathrm{Ca}$ intake and milk consumption were assessed by $48 \mathrm{~h}$ dietary recall. The lactose content of milk products was calculated as g lactose per $100 \mathrm{~g}$ milk and milk products consumed. Values are means, with standard errors represented by vertical bars. ${ }^{*} \mathrm{In}$ females, two-way ANOVA for lactase genotype $P=0.064$ and for interaction genotype $\times$ lactose content of milk products consumed $P=0.022$. In males, two-way ANOVA for lactase genotype $P=0.092$ and for interaction genotype $\times$ lactose content of milk products consumed $P=0.136$.

explained by the result suggesting that those who get symptoms from lactose or consumption of milk and milk products give up milk drinking and consume regularly other milk products that contain less lactose such as hard cheese, which is the most commonly used cheese type in Finland ${ }^{(19)}$, and sour milk products. Thus, only some lactose intolerants choose low-lactose milk and milk products where lactose has been enzymically digested.

In childhood and adolescence, the average daily lactose intake in the $\mathrm{C} / \mathrm{C}_{-13910}$ genotype varied from 19 to $36 \mathrm{~g}$ in females and from 35 to $46 \mathrm{~g}$ in males, and was $13 \mathrm{~g}$ and $19 \mathrm{~g}$ for adult females and males, respectively. Previous studies on the $\mathrm{C} / \mathrm{T}_{-13910}$ polymorphism have reported no habitual lactose intakes; thus we could not compare the lactose intake of the $\mathrm{C} / \mathrm{C}_{-13910}$ genotype in different populations. Considering the previous evidence on lactose intake in those with non-genetically confirmed lactose maldigestion ${ }^{(40-42)}$, especially in childhood the lactose intakes of our subjects with the $\mathrm{C} / \mathrm{C}_{-13910}$ genotype were quite high. Vesa et al. ${ }^{(40)}$ have shown that lactose maldigesters reported no differences in the severity of symptoms after consuming milk without lactose or milk with varying amounts of lactose $(0 \cdot 5-7 \mathrm{~g}$ per $200 \mathrm{ml}$ ). In addition, Hertzler et al. ${ }^{(41)}$ have shown that gastrointestinal symptoms from lactose maldigestion, measured with the hydrogen breath test, increase with doses exceeding $12 \mathrm{~g}$ lactose. A recent meta-analysis confirmed that the severity of gastrointestinal problems reported by lactose maldigesters did not differ after a lactose dose of $12 \mathrm{~g}$ (about $240 \mathrm{ml}$ milk) or after ingesting a placebo under masked conditions ${ }^{(42)}$. However, individual differences in lactose tolerance may be significant, since the development of intolerance symptoms depends not only on the dose of lactose, but also on the rate of gastric emptying and delivery of lactose to the colon $^{(43,44)}$, and the adaptation of colonic bacteria to frequent lactose consumption ${ }^{(45)}$. Furthermore, studies have shown that maldigesters who have experienced gastrointestinal problems after the consumption of large amounts of lactose may be psychologically sensitised to milk consumption ${ }^{(46)}$. Lactose is known to facilitate $\mathrm{Ca}$ absorption, but previous evidence suggests that at normal intake levels lactose does not seem to significantly affect the absorption of $\mathrm{Ca}$ from milk in lactase-deficient or lactase-sufficient subjects ${ }^{(47-49)}$. However, a recent study by Obermayer-Pietsch et al. ${ }^{(18)}$ showed that genetic lactase non-persistence is associated with decreased fractional $\mathrm{Ca}$ absorption when $\mathrm{Ca}$ is ingested with high amounts of lactose. Thus, together with our findings, these results suggest that a diet with lower lactose content may have beneficial effects on $\mathrm{Ca}$ intake and bioavailability in those with genetic lactase non-persistence.

Our previous results from the Cardiovascular Risk in Young Finns study showed that the lactase genotypes contributed significantly to dietary $\mathrm{Ca}$ intake from childhood into young adulthood $^{(32)}$. Because sufficient $\mathrm{Ca}$ intake is required for the optimal attainment of peak bone mass ${ }^{(50,51)}$, adequate $\mathrm{Ca}$ intake in children and adolescents should be assured. However, the differences in $\mathrm{Ca}$ intake between the lactase genotypes were less distinct than in other populations ${ }^{(15-17)}$, and the habitual $\mathrm{Ca}$ intakes of adult Finns are higher than those of adults in other European countries ${ }^{(19,52)}$. Nevertheless, in one-third of adult females and in one-quarter of males with the $\mathrm{C} / \mathrm{C}_{-13910}$ genotype, the daily $\mathrm{Ca}$ intake failed to meet the Finnish nutrition recommendations ${ }^{(34)}$. The lower total $\mathrm{Ca}$ intake in the $\mathrm{C} / \mathrm{C}_{-13910}$ genotype was mostly explained by lower milk consumption, and the higher cheese consumption only partly compensated for the genotype difference in daily $\mathrm{Ca}$ intake. It is noteworthy that those with 
the $\mathrm{C} / \mathrm{C}_{-13910}$ genotype had equal $\mathrm{Ca}$ intake when compared with other genotypes if they chose milk and milk products with lower lactose content.

The data on milk product consumption were collected by the semi-quantitative frequency questionnaire that was used to assess dietary habits on a long-term basis. The major limitation in our questionnaire is that it counts only the numbers of milk and milk product portions and fails to take into account the actual portion size. Fortunately, the same questions about the amount and frequency of milk product consumption and type of milk products consumed were used throughout the follow-up years, thus ensuring good comparability over time. Moreover, low-lactose milk products were not recorded separately from the milk products with normal lactose content. Despite this limitation, we were able to examine the preference for low-lactose milk and milk products because the subjects were asked to report on low-lactose and milk-free diets. In addition, from the dietary recall data we could calculate the lactose content of the milk products consumed.

The data on the subjects' daily intakes of $\mathrm{Ca}$ and lactose were obtained with a detailed $48 \mathrm{~h}$ dietary recall. Until the age of 12 years subjects were accompanied by their parents in the dietary recalls and from the age of 15 years they participated in the recalls on their own, which may have influenced the accuracy of the food recording. The estimation of portion sizes may have been better in childhood than in adolescence because children could ask help from their parents and because adolescents eat a larger proportion of the diet outside the home ${ }^{(53)}$. Ca and lactose intake seemed to decrease in females after the age of 12 years, while in males $\mathrm{Ca}$ and lactose intakes increased in adolescence. The most likely explanation for this finding is the underestimation of food intake that is common among adolescent females due to the preoccupation with body weight and image ${ }^{(54)}$. Furthermore, in both sexes the amount of milk and milk products consumed may reflect the pubertal growth spurt that in average occurs in girls between the ages of 11 and 14 and in boys aged 13-17 years $^{(55)}$.

In conclusion, the $\mathrm{C} / \mathrm{C}_{-13910}$ genotype was associated with a lower consumption of milk since childhood, predisposing females in particular to inadequate $\mathrm{Ca}$ intake. In adult females, the lactose content of milk products consumed was lower, and in both sexes low-lactose and milk-free diets were more common in the $\mathrm{C} / \mathrm{C}_{-13910}$ genotype than in the other genotypes. In adult females, preference for low-lactose milk and milk products equalised the differences in $\mathrm{Ca}$ intake between the genotypes. Thus, in those with the $\mathrm{C} / \mathrm{C}_{-13910}$ genotype preference for low-lactose milk and milk products may decrease the risk for inadequate $\mathrm{Ca}$ intake.

\section{Acknowledgements}

The present study has been financially supported by the Academy of Finland (grants no. 77841, 210283, 117941 and 117832), the Medical Research Fund of Tampere University Hospital, the Emil Aaltonen Foundation (T. J. L.), the Finnish Cultural Foundation (M. M. L. L.), Juho Vainio Foundation (M. M. L. L.), the Finnish Foundation for Cardiovascular Research, the Finnish Social Insurance Institution, the Yrjö Jahnsson Foundation, and federal grants to Turku University Hospital (O. T. R., J. S. A. V). We thank Stephen Stalter from the Language Centre, University of Helsinki, for the language revision. Data used in the analysis within the present paper was collected as part of the ongoing Cardiovascular Risk in Young Finns follow-up study. There are no conflicts of interest. M. M. L. L. conducted the study and wrote the paper. M. M. L. L. carried out the statistical analysis with the help of V. M.; R. R and T. J. L. were responsible for the lactase genotyping. V. M., L. R., R. R., T. J. L., J. S. A. V. and O. T. R. provided suggestions on the content and contributed to the revision of the manuscript.

\section{References}

1. Sahi T (1994) Genetics and epidemiology of adult-type hypolactasia. Scand J Gastroenterol 202, Suppl., S7-S20.

2. Montalto M, Curigliano V, Santoro L, et al. (2006) Management and treatment of lactose malabsorption. World J Gastroenterol 12, 187-191.

3. Honkanen R, Pulkkinen P, Järvinen R, et al. (1996) Does lactose intolerance predispose to low bone density? A population-based study of perimenopausal Finnish women. Bone 19, 23-28.

4. Honkanen R, Kröger H, Alhava E, et al. (1997) Lactose intolerance associated with fractures of weight-bearing bones in Finnish women aged 38-57 years. Bone 21, 473-477.

5. Goulding A, Taylor RW, Keil D, et al. (1999) Lactose malabsorption and rate of bone loss in older women. Age Ageing 28, $175-180$.

6. DiStefano M, Veneto G, Malservisi S, et al. (2002) Lactose malabsorption and intolerance and peak bone mass. Gastroenterology 122, 1793-1799.

7. Slemenda C, Christian J, Hui S, et al. (1991) No evidence for an effect of lactase deficiency on bone mass in premenopausal or postmenopausal women. J Bone Miner Res 6, 1367-1371.

8. Kudlacek S, Freudenthaler O, Weissböeck H, et al. (2002) Lactose intolerance: a risk factor for reduced bone mineral density and vertebral fractures? J Gastroenterol 37, 1014-1019.

9. Lanou AJ, Berkow SE \& Barnard ND (2005) Calcium, dairy products, and bone health in children and young adults: a reevaluation of the evidence. Pediatrics 115, 736-743.

10. Enattah NS, Sahi T, Savilahti E, et al. (2002) Identification of a variant associated with adult type hypolactasia. Nature Genetics 30, 233-237.

11. Olds LC \& Sibley E (2003) Lactase persistence DNA variant enhances lactase promotor activity in vitro: functional role as a cis regulatory element. Hum Mol Gen 12, 2333-2340.

12. Troelsen JT, Olsen J, Møller J, et al. (2003) An upstream polymorphism associated with lactase persistence has increased enhancer activity. Gastroenterology 125, 1686-1694.

13. Lewinsky RH, Jensen TGK, Møller J, et al. (2005) T-13910 DNA variant associated with lactase persistence interacts with Oct-1 and stimulates lactase promoter activity in vitro. Hum Mol Gen 14, 3945-3953.

14. Kuokkanen M, Enattah NS, Oksanen A, et al. (2003) Transcriptional regulation of the lactase-phlorizin hydrolase gene by polymorphisms associated with adult-type hypolactasia. Gut 52, 647-652.

15. Obermayer-Pietsch BM, Bonelli CM, Walter DE, et al. (2004) Genetic predisposition for adult lactose intolerance and relation to diet, bone density and bone fractures. J Bone Miner Res 19, $42-47$

16. Gugatschka M, Dobnig H, Fahrleitner-Pammer A, et al. (2005) Molecularly-defined lactose malabsorption, milk consumption and anthropometric differences in adult males. QJM 98, $857-863$.

17. Lember M, Torniainen S, Kull M, et al. (2006) Lactase non-persistence and milk consumption in Estonia. World J Gastroenterol 12, 7329-7331. 
18. Obermayer-Pietsch BM, Gugatschka M, Reitter S, et al. (2007) Adult- type hypolactasia and calcium availability: decreased calcium intake or impaired calcium absorption? Osteoporosis Int 18, 445-451.

19. Paturi M, Tapanainen H \& Reinivuo H, et al. (2008) The National FINDIET 2007 Survey. Publications of National Public Health Institute 2008, Series B B23. http://www.ktl.fi/ portal/suomi/osastot/eteo/yksikot/ravitsemusyksikko/finravinto_ tutkimus/finravinto_2007

20. Rasinperä H, Savilahti E, Enattah NS, et al. (2004) A genetic test which can be used to diagnose adult-type hypolactasia in children. Gut 53, 1571-1576.

21. Rasinperä H, Saarinen K, Pelkonen A, et al. (2006) Molecularly defined adult-type hypolactasia in school-aged children with a previous history of cow's milk allergy. World J Gastroenterol 12, 2264-2268.

22. Anthoni SR, Rasinperä HA, Kotamies AJ, et al. (2007) Molecularly defined adult-type hypolactasia among working age people with reference to milk consumption and gastrointestinal symptoms. World J Gastroenterol 28, 1230-1235.

23. Enattah N, Välimäki VV, Välimäki MJ, et al. (2004) Molecularly defined lactose malabsorption, peak bone mass and bone turnover rate in young Finnish men. Calsif Tissue Int 75, 488-493.

24. Enattah N, Pekkarinen T, Välimäki MJ, et al. (2005) Genetically defined adult-type hypolactasia and self-reported lactose intolerance as risk factors of osteoporosis in Finnish postmenopausal women. Eur J Clin Nutr 59, 1105-1111.

25. Enattah NS, Sulkava R, Halonen P, et al. (2005) Genetic variant of lactase-persistent C/T-13910 is associated with bone fractures in very old age. JAGS 53, 79-82.

26. Åkerblom HK, Viikari J, Uhari M, et al. (1985) Atherosclerosis precursors in Finnish children and adolescents. I. General description of the cross-sectional study of 1980, and an account of the children's and families' state of health. Acta Paediatr Scand 318, Suppl., S49-S63.

27. Räsänen L, Ahola M, Kara R, et al. (1985) Atherosclerosis precursors in Finnish children and adolescents. VIII. Food consumption and nutrient intakes. Acta Paediatr Scand 318, Suppl., S135-S153.

28. Åkerblom HK, Viikari J, Raitakari OT, et al. (1999) Cardiovascular Risk in Young Finns Study: general outline and recent developments. Ann Med 31, Suppl. 1, S45-S54.

29. Räsänen L, Laitinen S, Stirkkinen R, et al. (1991) Composition of the diet of young Finns in 1986. Ann Med 23, 73-80.

30. Raitakari OT, Juonala M, Rönnemaa T, et al. (2008) Cohort profile: the Cardiovascular Risk in Young Finns Study. Int $J$ Epidemiol 37, 1220-1226.

31. Mikkilä V, Räsänen L, Raitakari OT, et al. (2004) Longitudinal changes in diet from childhood into adulthood with respect to risk of cardiovascular diseases: The Cardiovascular Risk in Young Finns Study. Eur J Clin Nutr 58, 1038-1045.

32. Lehtimäki T, Hemminki J, Rontu R, et al. (2006) The effects of adult-type hypolactasia on body height growth and dietary calcium intake from childhood into young adulthood: a 21-year follow-up study - the Cardiovascular Risk in Young Finns Study. Pediatrics 118, 1553-1559.

33. National Public Health Institute (2003) Food Composition Databank Fineli, version FND2, 2003 (website in Finnish). http:// www.ktl.fi/fineli

34. National Nutrition Council (2005) Finnish Nutrition Recommendations 2005. Helsinki: Ministry of Agriculture and Forestry. http://wwwb.mmm.fi/ravitsemusneuvottelukunta/Etusivu_ ENG.htm

35. Livak KJ (1999) Allelic discrimination using fluorogenic probes and the $5^{\prime}$ nuclease assay. Genet Anal 14, 143-149.
36. Raymond M \& Rousset F (1995) GENEPOP (version 1.2): population genetics software for exact tests and ecumenicism. J Heredity 86, 248-249. http://genepop.curtin.edu.au

37. Onwulata CI, Rao DR \& Vankineni P (1989) Relative efficiency of yogurt, sweet asidophilus milk, hydrolyzed-lactose milk, and a commercial lactase tablet in alleviating lactose maldigestion. Am J Clin Nutr 49, 1233-1237.

38. Krause J, Kaltbeitzer I \& Erckenbrecht JF (1996) Lactose malabsorption produces more symptoms in women than in men. Gastroenterology 110, A339 (abstract).

39. Vesa TH, Seppo LM, Marteau PR, et al. (1998) Role of irritable bowel syndrome in subjective lactose intolerance. Am J Clin Nutr 67, 710-715.

40. Vesa TH, Korpela RA \& Sahi T (1996) Tolerance to small amounts of lactose in lactose maldigesters. Am J Clin Nutr 64, 197-201.

41. Hertzler SR, Huynh B-CL \& Savaiano DA (1996) How much lactose is low lactose? J Am Diet Assoc 96, 234-246.

42. Savaiano DA, Boushey CJ \& McCabe GP (2006) Lactose intolerance symptoms assessed by meta-analysis: a grain of truth that leads to exaggeration. J Nutr 136, 1107-1113.

43. Leichter J (1973) Comparison of whole milk and skim milk with aqueous lactose solution in lactose tolerance test. Am J Clin Nutr 26, 393-396.

44. Martini MC \& Savaiano DA (1988) Reduced intolerance symptoms from lactose consumed during a meal. Am J Clin Nutr 47, $57-60$.

45. Johnson AO, Semenya JG, Buchowski MS, et al. (1993) Adaptation of lactose maldigesters to continued milk intakes. Am J Clin Nutr 58, 879-881.

46. Suarez FL, Savaiano D, Arbisi P, et al. (1997) Tolerance to the daily ingestion of two cups of milk by individuals claiming lactose intolerance. Am J Clin Nutr 65, 1502-1506.

47. Tremaine WJ, Newcommer AD, Riggs L, et al. (1986) Calcium absorption from milk in lactase deficient and lactase sufficient adults. Dig Dis Sci 31, 376-378.

48. Griesen M, Cochet B, Infante F, et al. (1989) Calcium absorption from milk in lactase-deficient subjects. Am J Clin Nutr 49, 377-384.

49. Zitterman A, Bock P, Drummer C, et al. (2000) Lactose does not enhance calcium bioavailability in lactose-tolerant, healthy adults. Am J Clin Nutr 71, 931-936.

50. Välimäki MJ, Kärkkäinen M, Lamberg-Allardt C, et al. (1994) Exercise, smoking, and calcium intake during adolescence and early adulthood as determinants of peak bone mass. BMJ $\mathbf{3 0 9}$, 230-235.

51. Matkovic V, Landoll JD, Badenshop-Stevens NE, et al. (2004) Nutrition influences skeletal development from childhood to adulthood: a study of hip, spine, and forearm in adolescent females. J Nutr 134, Suppl., S701-S705.

52. Scientific Committee on Food (2003) Opinion of the Scientific Committee on Food on the tolerable upper intake level of calciums, Table 1, p. 3. http://ec.europa.eu/food/fs $/ \mathrm{sc} / \mathrm{scf} /$ out194_en.pdf

53. Livingstone MB, Prentice AM, Coward WA, et al. (1992) Validation of estimates of energy intake by weighed dietary record and diet history in children and adolescents. Am J Clin Nutr 56, 29-35.

54. Wardle J \& Beales S (1986) Restraint, body image and food attitudes in children from 12 to 18 years. Appetite 7, 209-217.

55. Theintz G, Buchs B, Rizzoli R, et al. (1992) Longitudinal monitoring of bone mass accumulation in healthy adolescents: evidence for a marked reduction after 16 years of age at the levels of lumbar spine and femoral neck in female subjects. $J$ Clin Endocrinol Metab 75, 1060-1065. 